\title{
Debate sobre o artigo de Paim
}

Debate on the paper by Paim

Debate acerca del artículo de Paim

http://dx.doi.org/10.1590/0102-311XC0011013

Amélia Cohn

Mestrado em Saúde Coletiva, Universidade Católica de Santos, Santos, Brasil. cohn.amel@gmail.com

\section{Comentário do texto de Jairnilson Paim: discordando mas nem tanto}

Comentar análise de um dos pensadores mais consistentes no âmbito da Saúde Coletiva no Brasil não é tarefa fácil. A precisão e o acerto de sua análise neste texto mais uma vez confirmam sua seriedade, fundamentação analítica, e o senso de oportunidade que dela emanam.

Após uma revisão histórica da constituição de nosso sistema de proteção social, a partir da reconstrução dos principais traços históricos da conjuntura internacional e nacional, Paim lança uma tese forte: a de que a política social no Brasil no período 2003-2012 consolida um processo de americanização da questão social. Para desenvolvê-la lança mão dos programas Bolsa Família, do Benefício de Prestação Continuada, do subfinanciamento do SUS, e das tendências atuais das políticas de saúde.

Não deixa de apontar, ainda, o processo de absorção dos quadros sanitaristas e reformistas pela máquina governamental; no entanto, neste ponto não aponta com o necessário destaque algo fundamental, a meu ver, da própria natureza do processo de reforma sanitária brasileiro: o fato de ele ter se dado a partir do interior do Estado, via estratégia de "ocupação de espaços públicos” pelos quadros reformistas. E por que isto é importante? Por três razões: (1) apesar de as origens das propostas de democratização da saúde terem se dado no interior da sociedade, o processo de sua implementação centrou-se no Estado, distanciando-se da sociedade; (2) ainda em decorrência dessa estratégia, no decorrer desses 25 anos não se diferenciou e não se distanciou a relação entre "implementadores" e sujeitos da sociedade. A comunidade sanitarista tende a se confundir e portanto não se diferenciar entre quem está dentro do Estado e quem está fora do Estado. E assim os conflitos de interesses, quando emergem, aparecem indiferenciados, fazendo com que qualquer crítica aos caminhos atuais tomados pelo SUS constitua uma crítica aos princípios da reforma sanitária. Aliás, as críticas do autor neste texto são revalorizadas por esse nosso traço sanitarista histórico. E (3) pelo fato de que, como assinalava nosso saudoso Guilhermo O’Donnell, nossa transição democrática, ao contrário do caso argentino por exemplo, se deu não por ruptura, o que o levava a qualificá-la como uma "transição pactuada". Isto significa que a redemocratização brasileira foi (e vem sendo, acrescento) marcada pela aliança entre uma oposição moderada (incluindo aí ambos os projetos de reforma sanitária mencionados por Paim) e dissidentes do regime militar. Mas é o próprio cientista político que adverte que a realidade da consolidação democrática demanda modificações marcantes dos acordos que viabilizaram a transição para a democracia, e que seria isso que representaria a possibilidade de realização de reformas estruturais da realidade social (brasileira, no nosso caso) que não foram possíveis quando da transição 1 .

Uma segunda tese, igualmente forte, defendida por Paim é a de que permanece uma tensão no interior do nosso processo de redemocratização e de consolidação democrática entre propostas assistencialistas e propostas universalizantes. Ou nos termos de Eduardo Fagnani, a tensão entre uma proposta neoliberal e uma pautada pela seguridade social, segundo os preceitos constitucionais. E deve-se associar a esta tensão o fato de que, ao contrário da tendência atual, que consiste em enfatizar que a desigualdade social e o combate à questão social é equacionada entre ricos e pobres, e não mais entre classes sociais, leva a uma crescente tecnificação das políticas sociais, o que traz profundas reformulações da concepção de direitos universais da cidadania. Não há como discordar do autor.

Mas deve-se apontar para duas consequências disso: na ausência de um projeto de sociedade e de nação, as políticas de saúde e do SUS acabam por ser vítimas de uma maior vulnerabilidade a demandas concretas, imediatas e fragmentadas da sociedade, levando a uma crescente segmentação da oferta, e consequentemente da clientela, contrária à concepção de direitos. De fato, o que se verifica nos últimos anos é a somatória sucessiva de programas e políticas por parte do Ministério da Saúde, sem que esta somatória se traduza num sistema de saúde articulado e que aponte para a universalidade, integralidade e equidade.

Em consequência, são os interesses privados da assistência médica (lucrativa e filantrópica), provedora e produtora dos serviços médicos que acabam por ganhar força. Mais que isso, são eles que penetram no interior do Estado, não mais como "anéis burocráticos", mas compondo o próprio Estado, na administração indireta. Haja vista as duas gestões da ANS, que tem como seus presidentes dos militantes do setor privado 
da saúde. Por outro lado, na administração pública direta, terceiriza-se a gerência dos serviços de saúde, imprimindo-lhes uma nova filosofia de gestão: a racionalidade privada na produção de serviços que assim é transplantada para o interior da administração direta. Portanto, não se trata mais de uma "privatização da saúde" como aquela dos finais dos anos 60 e que vingaram nas décadas posteriores.

Atualmente o processo de privatização é muito mais sofisticado e complexo, tal como se complexificou o subsistema privado da saúde, e tal como foram esvaziados os princípios do SUS ao longo de sua implantação. O ideário predominante passa então a ser o do custo/efetividade, em nome da qual se privatiza a saúde. O que não mudou, no entanto, foi o fato de o setor privado da saúde continuar na sua lógica histórica, e que segue sendo financiada pelo Estado, de forma direta ou indireta, de crescer e reproduzir seus lucros num mercado sem os riscos do mercado. Haja vista, mais uma vez, a medida recente de favorecer seguros populares de saúde, o que no nosso caso significa falar em seguros de saúde baratos (sic) com baixa cobertura, que certamente sobrecarregarão o subsistema público de saúde.

Assim, há que se investigar, na atual conjuntura, o que vem a ser a natureza pública e a natureza privada dos serviços médicos e de saúde, que estão borrando crescentemente suas fronteiras em decorrência das políticas de saúde recentes. E há que se investigar a razão pela qual a saúde, nesse período recente, foi a política setorial que menos avançou dentre as políticas sociais, $\mathrm{o}$ que contrasta com o período imediatamente pós 1988 e anos 1990.

Finalmente, Paim aposta nas forças progressistas da sociedade civil para ressuscitar as propostas originais da reforma sanitária e fazer com que elas sejam assumidas pelo Estado (ele se refere a governos). O problema reside no fato da ausência - ou sendo mais otimista, incapacidade de identificá-las - de forças progressistas organizadas e mobilizadas na sociedade, e que sejam articuladas por um projeto comum, como foi nosso caso dentre os reformistas sanitários dos anos 1970. Havia disputas no interior do movimento, porém existia um projeto maior, no interior do qual se definiam ganhadores e perdedores. O clima hoje talvez seja de que somos todos perdedores, apesar de todos os avanços e conquistas destes últimos 25 anos, com exceção daqueles que caíram no canto sedutor das novas formas de gestão dos serviços públicos de saúde ou no entorno do aparato estatal.

Mas aí estão as utopias para que não abandonemos a luta!

1. O’Donnell G, Schmitter PC, Whithead L. Transitions from authoritarian rule. v. 4. Tentative conclusions about uncertain democracies. Baltimore: Johns Hopkins University Press; 1986.

http://dx.doi.org/10.1590/0102-311XCO021013

Sarah Escorel

Escola Nacional de Saúde Pública Sergio Arouca, Fundação Oswaldo Cruz, Rio de Janeiro, Brasil. sescorel@ensp.fiocruz.br

\section{Efetivar a reforma sanitária por meio da participação social}

Em junho passado, as manifestações que tomaram as ruas do país, eclodindo em torno do aumento da passagem dos transportes públicos, apresentaram como principais reivindicações saúde, educação e, sobretudo, participação; a possibilidade de interferir nas decisões que afetam a vida do dia a dia nas cidades.

Moradores da Rocinha, em protesto na frente da casa do governador fluminense, declararam que não queriam a construção do teleférico previsto no PAC2 enquanto existissem 16 "valões" (esgoto a céu aberto) na comunidade. E, sobretudo, afirmaram que querem participar, ser ouvidos sobre a realidade local, estabelecer as prioridades em conjunto com as autoridades governamentais.

Quantos dos manifestantes têm conhecimento de que há quase 25 anos existem Conselhos e Conferências de Saúde no SUS, um imenso sistema de participação social envolvendo 72 mil conselheiros em todas as esferas governamentais, número maior do que o de vereadores brasileiros, dos quais 36 mil representam os usuários do sistema? E que o processo da última Conferência Nacional de Saúde (14a; 2011) abarcou centenas de milhares de brasileiros em 4.537 conferências (municipais e estaduais) e 4.500 participantes discutiram seu relatório final? 1. Quantos pensaram na possibilidade de pressionar, por meio dos Conselhos, ou de se fazerem presentes nas Conferências de Saúde, apresentando suas demandas de melhoria do atendimento e suas críticas à privatização em marcha dos serviços de saúde?

Certamente poucos, pouquíssimos. E mesmo que conhecessem esses espaços, sentir-se-iam representados? Teriam interesse em participar? Ou ao considerar que ali se desenvolve um jogo de cartas marcadas, tão burocratizado quanto o dos partidos políticos, inócuo na diminuição das desigualdades sociais e na efetivação dos direitos, pensariam ser melhor desenvolver algo 